\title{
In Vitro Effect of Sodium Fluoride on Malondialdehyde Concentration and on Superoxide Dismutase, Catalase, and Glutathione Peroxidase in Human Erythrocytes
}

\author{
José Gutiérrez-Salinas, ${ }^{1}$ Liliana García-Ortíz, ${ }^{2}$ José A. Morales González, ${ }^{3}$ \\ Sergio Hernández-Rodríguez, ${ }^{1}$ Sotero Ramírez-García, ${ }^{4}$ \\ Norma R. Núñez-Ramos, ${ }^{4}$ and Eduardo Madrigal-Santillán ${ }^{3}$ \\ ${ }^{1}$ Laboratory of Biochemistry and Experimental Medicine, Biomedical Research Division, National Medical Center \\ "20 de Noviembre," ISSSTE, Sn. Lorenzo No. 502, $2^{\circ}$ piso, Col. Del Valle, 03100 México, DF, Mexico \\ ${ }^{2}$ División of Genomic Medicine, National Medical Center "20 de Noviembre," ISSSTE, Sn. Lorenzo No. 502, \\ $2^{\circ}$ piso, Col. Del Valle, 03100 México, DF, Mexico \\ ${ }^{3}$ Laboratorio Medicina de Conservación, Escuela Superior de Medicina, Instituto Politécnico Nacional, \\ Plan de San Luis y Díaz Mirón, Col. Casco de Santo Tomás, Del. Miguel Hidalgo, 11340 México, DF, Mexico \\ ${ }^{4}$ Uromédica OSF, Calle Uxmal 422, Colonia Vértiz Narvarte, 03020 México, DF, Mexico
}

Correspondence should be addressed to José Gutiérrez-Salinas; quauhtlicutli@yahoo.com

Received 27 June 2013; Accepted 21 August 2013

Academic Editors: A. Basu, C. Montoliu, J. Pungercar, and E. Shibata

Copyright (C) 2013 José Gutiérrez-Salinas et al. This is an open access article distributed under the Creative Commons Attribution License, which permits unrestricted use, distribution, and reproduction in any medium, provided the original work is properly cited.

\begin{abstract}
The aim of this paper was to describe the in vitro effect of sodium fluoride $(\mathrm{NaF})$ on the specific activity of the major erythrocyte antioxidant enzymes, as well as on the membrane malondialdehyde concentration, as indicators of oxidative stress. For this purpose, human erythrocytes were incubated with $\operatorname{NaF}(0,7,28,56$, and $100 \mu \mathrm{g} / \mathrm{mL})$ or $\mathrm{NaF}(100 \mu \mathrm{g} / \mathrm{mL})+$ vitamin E $(1,2.5,5 \mathrm{and} 10 \mu \mathrm{g} / \mathrm{mL})$. The malondialdehyde (MDA) concentration on the surface of the erythrocytes was determined, as were the enzymatic activities of superoxide dismutase (SOD), catalase (CAT), and glutathione peroxidase (GlPx). Our results demonstrated that erythrocytes incubated with increasing NaF concentrations had an increased MDA concentration, along with decreased activity of antioxidant enzymes. The presence of vitamin $\mathrm{E}$ partially reversed the toxic effects of $\mathrm{NaF}$ on erythrocytes. These findings suggest that NaF induces oxidative stress in erythrocytes in vitro, and this stress is partially reversed by the presence of vitamin $\mathrm{E}$.
\end{abstract}

\section{Introduction}

Fluoride is a halide ion that is abundant on earth and in humans and is important for the proper development of bones and teeth. However, an excess of fluoride in the body can cause fluorosis, which may occur in an acute or chronic form [1-3]. Fluorosis is a serious public health problem, especially in developing countries, where the main source of intoxication is drinking water, which may exceed a fluoride concentration of $1 \mathrm{ppm}[1,2]$. Fluorosis in humans causes alterations in the musculoskeletal, nervous, digestive, and hematopoietic systems [1-3].
In vertebrates (including humans), hematologic disorders are the most commonly found pathologies in subjects with fluorosis, with the following being the most important: (a) hypochromic anemia, (b) variation in the size and shape of erythrocytes, (c) presence of Heinz bodies, (d) eosinophilic leukocytosis and lymphopenia, (e) increase in the amount of methemoglobin, and (f) alterations in hematocrit. Additionally, several biochemical and structural alterations have been described in erythrocytes exposed to fluoride compounds in vitro [4-10].

Oxidative stress is a recognized mechanism of damage caused by exposure to fluoride. Oxidative stress in response 
to fluoride has been observed in different types of cells and tissues experimentally exposed in vitro or in vivo, as well as in the tissues of animals and people living in endemically fluoridated areas [10-15].

Oxidative stress is characterized by an excess of reactive oxygen species (ROS) that react with the main cellular macromolecules, causing alterations in cellular homeostasis $[16,17]$. The main damage caused by ROS is lipid peroxidation of the polyunsaturated fatty acids of cellular membranes, from which malondialdehyde (MDA) is produced as a product. Moreover, the activity of the main antioxidant enzymes, such as superoxide dismutase (SOD), catalase (CAT) and glutathione peroxidase $(\mathrm{GlPx})$, is also affected $[16,17]$.

The most important antioxidant systems in erythrocytes are the SOD, CAT, and GlPx enzymes, as well as oxidized/reduced glutathione and vitamin $\mathrm{E}$ (Vit-E); Vit-E is the main antioxidant defense of cell membranes [16-19].

As mentioned above, fluoride poisoning causes several types of alterations in erythrocytes. However, the physiopathological mechanism by which these alterations occur is not fully understood. Nevertheless, it is believed that ROS production may be one of the mechanisms of damage caused by fluoride because it has been reported that these compounds inhibit antioxidant enzyme activity and increase MDA concentration in various experimental models [14, 15]. In vitro studies evaluating the antioxidant systems of erythrocytes exposed to fluoride are scarce. The aim of this study was to determine the effect of sodium fluoride $(\mathrm{NaF}$, as a source of fluoride) on the enzymatic activity of SOD, CAT, and GIPx and on MDA concentration in erythrocytes exposed to this toxin in vitro. Furthermore, we aimed to evaluate the antioxidant role of Vit-E against the possible toxic effects of fluoride.

\section{Materials and Methods}

2.1. Sampling. After an informed consent agreement was signed, a single blood sample was taken from healthy male subjects ( $n=5 ; 25$ to 30 y.o.) by venipuncture, using a Vacutainer system in tubes with anticoagulant (citrate). The samples were centrifuged at $500 \mathrm{~g}$ for $15 \mathrm{~min}$. to remove plasma and buffy coat. The cells were then washed three times by centrifuging with cold phosphate buffered saline (PBS). The packed erythrocytes were then resuspended in PBS to obtain 50\% hematocrit and used for incubation [20, 21].

All procedures were performed in accordance with the general rules and procedures approved by our institution's Ethics and Investigation Committee, who approved this study protocol.

2.2. Erythrocyte Treatment. Erythrocytes samples were incubated in duplicate according to previously established protocols [20]. Briefly, we proceeded as follows: $0.25 \mathrm{~mL}$ of packed erythrocytes was placed in test tubes, and $2.75 \mathrm{~mL}$ of PBS was added. This solution was incubated for 10 minutes at $37^{\circ} \mathrm{C}$ under constant stirring. After this adaptation time, the cells were divided into the following study groups: group A: $10 \mu \mathrm{L}$ of $\mathrm{NaF}$ solution to a final concentration of 7,28 ,
56 and $100 \mu \mathrm{g} / \mathrm{mL}$ and, group B: $10 \mu \mathrm{L}$ of $\mathrm{NaF}$ solution to a final concentration of $100 \mu \mathrm{g} / \mathrm{mL}$, supplemented with Vit-E at different concentrations (1, 2.5, 5 and $10 \mu \mathrm{L} / \mathrm{mL})$. Vit-E was dissolved in $0.05 \%$ ethanol in PBS; preliminary experiments showed that there was no apparent effect of the ethanol. $\mathrm{NaF}$ and Vit-E concentrations were chosen in accordance with previous reports [22-24]. For each treatment, five independent treatments were performed. As a control group, erythrocytes incubated under the same experimental conditions but without the presence of $\mathrm{NaF}$ or Vit-E were used.

After the erythrocytes were incubated for 3 hours at $37^{\circ} \mathrm{C}$ under constant stirring, the samples were centrifuged at $800 \mathrm{rpm}$ for 5 minutes and washed three times with cold PBS. Erythrocytes were then used to isolate cytosol and cell membranes.

2.3. Cytosol and Cell Membrane Isolation. To obtain the cytosol and cell membranes, erythrocytes were lysed using a hypotonic phosphate buffer $(5 \mathrm{P} 8 ; 5 \mathrm{mM}$ phosphate buffer solution, pH 8) [21]. Briefly, we proceeded as follows: one aliquot of erythrocytes was mixed with five aliquots of 5P8 solution under mild stirring for 15 minutes at $4^{\circ} \mathrm{C}$. The samples were then centrifuged at $10,000 \mathrm{rpm}$ for 15 minutes, and the supernatant (cytosol) was separated from the pellet and stored until further use. The pellet was washed with 5P8 at $10,000 \mathrm{rpm}$ until a smooth precipitate was obtained. The final precipitate (cell membranes) was resuspended in 200$250 \mu \mathrm{L}$ of cold PBS and stored until further use. Total protein concentration of the membranes was determined according to Lowry technique [25], using bovine serum albumin as a standard.

2.4. Malondialdehyde (MDA) Determination. MDA concentration in erythrocyte membranes was determined using a colorimetric commercial kit (TBARS Assay Kit, Cayman Chemical Co., Ann Arbor, MI, USA) following the manufacturer's protocol. MDA determination was based on the spectrophotometric detection at $530 \mathrm{~nm}$ (using a Jenway 6300 spectrophotometer, Cielo Vista, CA, USA) of the thiobarbituric acid-MDA adduct formed when heated under acidic conditions, according to the method reported by Yagi [26]. MDA determination (by triplicate) was performed with $300 \mathrm{mg}$ of total membrane protein, and the concentration was expressed in units of $\mathrm{nmol} / \mathrm{mg}$ protein.

2.5. Antioxidant Enzyme Activity Determination. To determine the activity of the antioxidant enzymes SOD, CAT, and GIPx in the cytosol of erythrocytes, we first eliminated the excess hemoglobin using the method reported by J. V. Bannister and W. H. Bannister [27]. A sample of cytosol was mixed (v/v) with an ethanol/chloroform solution $(5 / 3$, $\mathrm{v} / \mathrm{v}$ ) under constant stirring for 10 minutes. A 1/5 volume of isotonic $\mathrm{NaCl}$ was then added under constant stirring. The resulting solution was centrifuged at $3000 \mathrm{rpm}$ for 60 minutes to recover the hemoglobin-free supernatant (HbFS) to determine the activity of the enzymes. 
The activity of SOD, CAT, and GlPx was determined in HbFS samples (by triplicate each one) using commercial kits (Superoxide Dismutase Assay Kit; Catalase Assay Kit; Glutathione Peroxidase Assay Kit; Cayman Chemical Co.) following the manufacturer's protocol for each kit. Spectrophotometric analyses were performed using a Jenway 3600 spectrophotometer, and the activity of each enzyme was reported as $\mathrm{U} / \mathrm{g} \mathrm{Hb}(\mathrm{SOD})$ or $\mu \mathrm{mol} / \mathrm{min} / \mathrm{g} \mathrm{Hb}$ (CAT and GlPx).

2.6. Total Hemoglobin Determination. The concentration of total hemoglobin was determined in cytosol samples using a conventional method with Drabkin's reagent, and a standard curve is read at $540 \mathrm{~nm}$ in a spectrophotometer [28].

2.7. Statistical Analysis. The results are expressed as the mean \pm standard deviation (S.D.) and were analyzed using GraphPad Prism V 4.00 Statistical Software (GraphPad Software, San Diego, CA, USA). The results were evaluated using Student's $t$-test taking $P<0.05$ as statistically significant.

\section{Results}

3.1. The Effect of NaF on the Concentration of MDA in the Membrane of Erythrocytes. As shown in Figure 1(a), there was a statistically significant increase in MDA concentration on the membrane of the erythrocytes exposed to increasing concentrations of $\mathrm{NaF}$ compared with the control. The mean MDA concentration in the control group was $0.093 \pm$ $0.019 \mathrm{nmol} / \mathrm{mg}$ protein, whereas, with the lowest $\mathrm{NaF}$ concentration $(7 \mu \mathrm{g} / \mathrm{mL})$, there was a statistically significant fourfold increase in MDA concentration $(0.389 \pm 0.05 \mathrm{nmol} / \mathrm{mg}$ protein; $P<0.005)$. This concentration increased up to ninefold $(0.823 \pm 0.072 \mathrm{nmol} / \mathrm{mg}$ protein; $P<0.005)$ with the highest $\mathrm{NaF}$ concentration $(100 \mu \mathrm{g} / \mathrm{mL})$.

Because the greatest increase in MDA concentration was obtained with $100 \mu \mathrm{g} / \mathrm{mL} \mathrm{NaF}$, this concentration of the toxin was used to incubate the erythrocytes to determine the effect that increasing concentrations of Vit-E $(1,2.5,5$, and $10 \mu \mathrm{g} / \mathrm{mL}$ ) had on MDA production, as shown in Figure 1(b).

The incubation of erythrocytes with $100 \mu \mathrm{g} / \mathrm{mL} \mathrm{NaF}$ alone with 1 or $2.5 \mu \mathrm{g} / \mathrm{mL}$ Vit-E had no effect on the MDA concentration produced by NaF. However, incubation with 5 and $10 \mu \mathrm{g} / \mathrm{mL}$ Vit-E produced a statistically significant $(P<$ $0.05)$ decrease of $35 \%(0.535 \pm 0.0318 \mathrm{nmol} / \mathrm{mg}$ protein $)$ and $47 \%(0.435 \pm 0.04 \mathrm{nmol} / \mathrm{mg}$ protein $)$ in MDA concentration, respectively, in comparison with the group incubated with $100 \mu \mathrm{g} / \mathrm{mL} \mathrm{NaF}(\mathrm{MDA}=0.836 \pm 0.064 \mathrm{nmol} / \mathrm{mg}$ protein $)$. However, the decrease in MDA concentration produced by the presence of Vit-E was still 4-5 times higher than that of the control group (MDA control $=0.089 \pm 0.014 \mathrm{nmol} / \mathrm{mg}$ protein, Figure 1(b)).

3.2. Effect of NaF and Vit-E on the Activity of Antioxidant Enzymes. The activities of SOD, CAT, and GlPx in erythrocytes incubated with increasing concentrations of $\mathrm{NaF}$ or with $100 \mu \mathrm{g} / \mathrm{mL} \mathrm{NaF}+$ different concentrations of Vit-E are shown in Figures 2, 3, and 4, respectively.

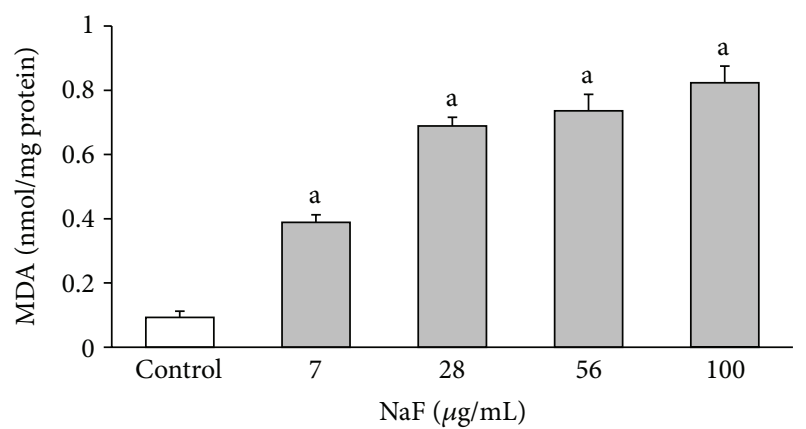

(a)

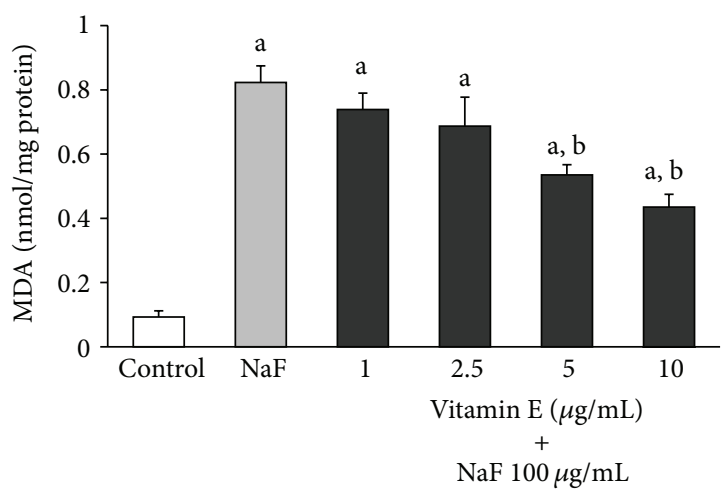

(b)

FIGURE 1: MDA concentration in the membrane of erythrocytes incubated 3 hours with increasing concentrations of sodium fluoride (NaF) (a) or incubated with $100 \mu \mathrm{g} / \mathrm{mL} \mathrm{NaF}$ or $100 \mu \mathrm{g} / \mathrm{mL} \mathrm{NaF}$ with Vit-E in increasing concentrations (b). The results are expressed as the mean \pm standard deviation of five independent experiments, taking two samples per experiment and performing the determinations in triplicate. ${ }^{\mathrm{a}} \mathrm{P}<0.05$ compared with the control group; ${ }^{\mathrm{b}} \mathrm{P}<0.05$ compared with the group incubated with only $100 \mu \mathrm{g} / \mathrm{mL} \mathrm{NaF}$.

The incubation of erythrocytes with increasing $\mathrm{NaF}$ concentrations produced a statistically significant decrease in the activity of all enzymes. This inhibition was obtained from the lowest $\mathrm{NaF}$ concentration $(7 \mu \mathrm{g} / \mathrm{mL})$ and reached its maximum with the highest concentration $(100 \mu \mathrm{g} / \mathrm{mL})$ of $\mathrm{NaF}$ (Section (a) of Figures 2 to 4). However, the inhibitory effect that the highest concentration of $\mathrm{NaF}(100 \mu \mathrm{g} / \mathrm{mL})$ had on the activity of the enzymes was partially counteracted when the cells were incubated with increasing concentrations of Vit-E (Section (b) of Figures 2 to 4 ).

The activity of SOD was inhibited by $16.3 \%$ compared with the control when the erythrocytes were incubated with $7 \mu \mathrm{g} / \mathrm{mL} \mathrm{NaF}(700 \pm 50 \mathrm{U} / \mathrm{g}$ Hb versus $836.25 \pm 58.53 \mathrm{U} / \mathrm{g} \mathrm{Hb}$; $P<0.05)$. This inhibition reached $79.75 \%(169.36 \pm 38.2 \mathrm{U} / \mathrm{g}$ $\mathrm{Hb}$ ) with a concentration of $100 \mu \mathrm{g} / \mathrm{mL} \mathrm{NaF}$ (Figure 2(a)).

Moreover, when the erythrocytes were incubated with $100 \mu \mathrm{g} / \mathrm{mL} \mathrm{NaF}$ along with increasing concentrations of Vit$\mathrm{E}$, there was a partial reversal of the inhibitory effect of $\mathrm{NaF}$, which suggested an increase in SOD activity due to the effect of Vit-E (Figure 2(b)).

Thus, erythrocytes incubated with only $100 \mu \mathrm{g} / \mathrm{mL} \mathrm{NaF}$ showed an average of $172.41 \pm 38.2 \mathrm{U} / \mathrm{g} \mathrm{Hg}$ SOD activity. This 


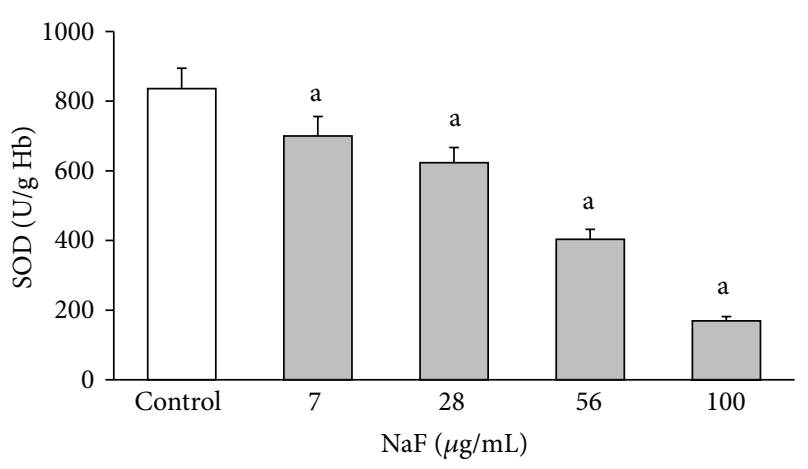

(a)

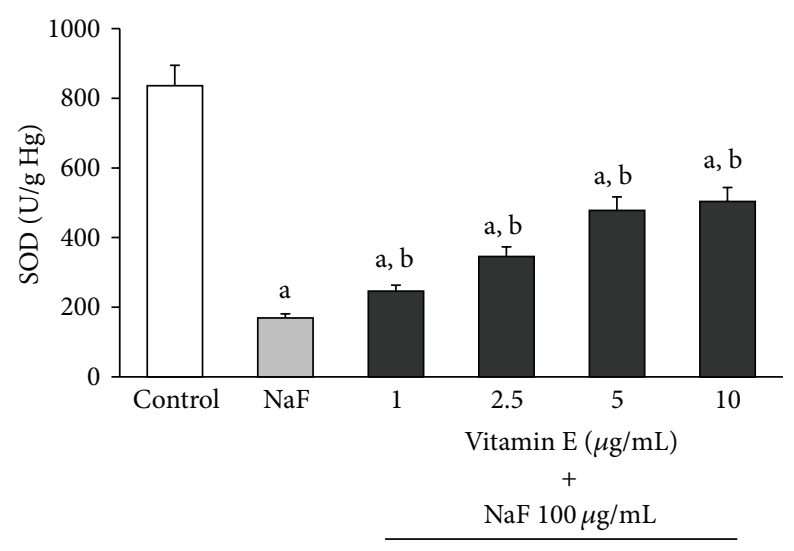

(b)

FIGURE 2: SOD activity in erythrocytes incubated in vitro for 3 hours with increasing concentrations of $\mathrm{NaF}$ (a) or incubated with $100 \mu \mathrm{g} / \mathrm{mL} \mathrm{NaF}$ or $100 \mu \mathrm{g} / \mathrm{mL} \mathrm{NaF}$ with Vit-E in increasing concentrations (b). The results are expressed as the mean \pm standard deviation of five independent experiments, taking two samples per experiment and performing the determinations in triplicate. ${ }^{\text {a }} P<$ 0.05 compared with the control group; ${ }^{\mathrm{b}} P<0.05$ compared with the group incubated with only $100 \mu \mathrm{g} / \mathrm{mL} \mathrm{NaF}$.

represents an inhibition of 79.2\% $(P<0.05)$ compared with the control, which showed an average of $828.32 \pm 48.33 \mathrm{U} / \mathrm{g}$ Hg SOD activity (Figure 2(b)). However, when erythrocytes were incubated with $100 \mu \mathrm{g} / \mathrm{mL} \mathrm{NaF}$ and $1 \mu \mathrm{g} / \mathrm{mL}$ Vit-E, the average SOD activity was $245.89 \pm 45 \mathrm{U} / \mathrm{g} \mathrm{Hg}$, representing $29.7 \%$ of the activity of the control. However, this value represents a statistically significant increase $(P<0.05)$ of $42.61 \%$ compared with the activity of this enzyme when the erythrocytes were incubated with only $100 \mu \mathrm{g} / \mathrm{mL} \mathrm{NaF}$. The increase in SOD activity due to the presence of Vit-E $(10 \mu \mathrm{g} / \mathrm{mL})$ was up to $60.8 \%(503.49 \pm 52 \mathrm{U} / \mathrm{g} \mathrm{Hg})$ compared with the control. This represents a significant increase $(P<$ 0.05 ) of $192.03 \%$ compared with the activity this enzyme shows in erythrocytes incubated with only $100 \mu \mathrm{g} / \mathrm{mL} \mathrm{NaF}$ (Figure 2(b)).

Similar to SOD, the activities of CAT and GlPx were inhibited when the erythrocytes were incubated in increasing $\mathrm{NaF}$ concentrations (Figures 3(a) and 4(a), resp.).

The mean activity of CAT in erythrocytes incubated under standard conditions (control) was $532.43 \pm 37.27 \mu$ $\mathrm{mol} / \mathrm{min} / \mathrm{g} \mathrm{Hg}$. This activity decreased significantly $(P<$

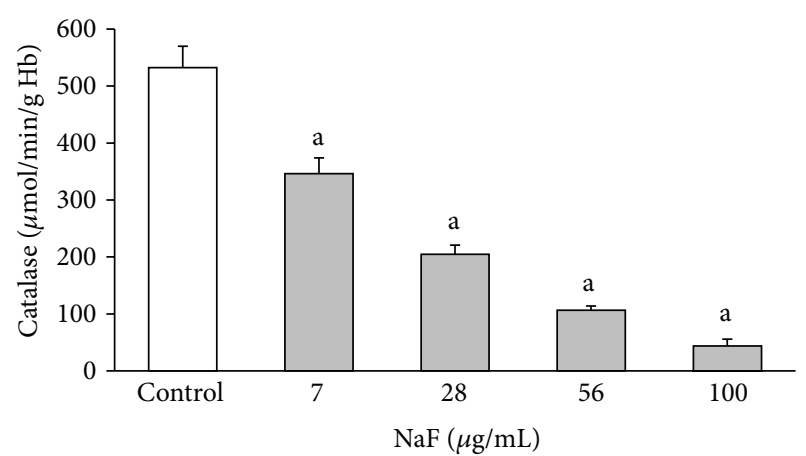

(a)

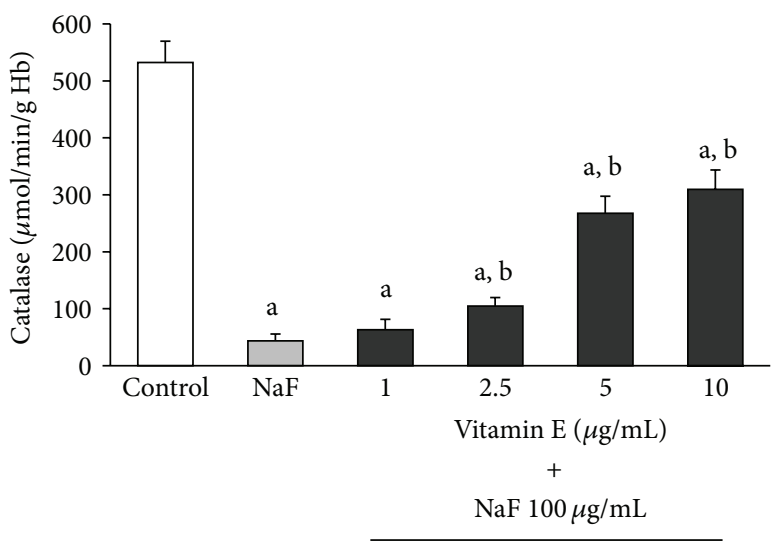

(b)

FIGURE 3: CAT activity in erythrocytes incubated under the same conditions described in Figure 2. The results are expressed as the mean \pm standard deviation of five independent experiments, taking two samples per experiment and performing the determinations in triplicate. ${ }^{\mathrm{a}} P<0.05$ compared with the control group; ${ }^{\mathrm{b}} P<0.05$ compared with the group incubated with only $100 \mu \mathrm{g} / \mathrm{mL} \mathrm{NaF}$.

$0.05)$ to $65.02 \%(346.2 \pm 38.3 \mu \mathrm{mol} / \mathrm{min} / \mathrm{g} \mathrm{Hg})$ of the control with an $\mathrm{NaF}$ concentration of $7 \mu \mathrm{g} / \mathrm{mL}$ and decreased up to $91.81 \%(43.59 \pm 25.2 \mu \mathrm{mol} / \mathrm{min} / \mathrm{g} \mathrm{Hg})$ with a concentration of $100 \mu \mathrm{g} / \mathrm{mL} \mathrm{NaF}$ (Figure 3(a)). Furthermore, with a concentration of $2.5 \mu \mathrm{g} / \mathrm{mL}$ Vit-E in the culture media of erythrocytes exposed to $100 \mu \mathrm{g} / \mathrm{mL} \mathrm{NaF}$, a significant increase $(P<0.05)$ in CAT activity was observed. The increase in CAT activity was higher with increasing Vit-E concentrations, reaching up to $61.94 \%$ of the activity of the control with a concentration of $10 \mu \mathrm{g} / \mathrm{mL}$ Vit-E. This represents a 7.52 -fold increase in the activity of this enzyme compared with the activity in erythrocytes incubated with only $100 \mu \mathrm{g} / \mathrm{mL} \mathrm{NaF}(41.18 \pm$ $22.31 \mu \mathrm{mol} / \mathrm{min} / \mathrm{g} \mathrm{Hg}$ versus $309.7 \pm 42.2 \mu \mathrm{mol} / \mathrm{min} / \mathrm{g} \mathrm{Hg}$; $P<0.05$, (Figure 3(b)).

As with SOD and CAT, GlPx showed a decrease in its activity with increasing $\mathrm{NaF}$ concentrations. This inhibition was up to $77 \%(14.56 \pm 6.4 \mu \mathrm{mol} / \mathrm{min} / \mathrm{g} \mathrm{Hg})$ of the control $(63.56 \pm 5.08 \mu \mathrm{mol} / \mathrm{min} / \mathrm{g} \mathrm{Hg})$ with the highest $\mathrm{NaF}$ concentration $(100 \mu \mathrm{g} / \mathrm{mL}$ ) (Figure $4(\mathrm{a})$ ). The presence of increasing concentrations of Vit-E in erythrocytes exposed to $100 \mu \mathrm{g} / \mathrm{mL}$ $\mathrm{NaF}$ significantly increased the activity of GlPx from $13.85 \pm$ $5.1 \mu \mathrm{mol} / \mathrm{min} / \mathrm{g} \mathrm{Hg}$ (only with $100 \mu \mathrm{g} / \mathrm{mL} \mathrm{NaF}$ ) to $39.37 \pm$ 


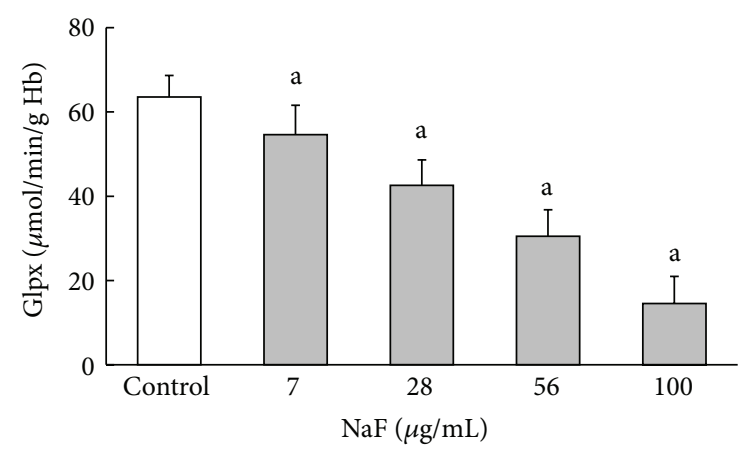

(a)

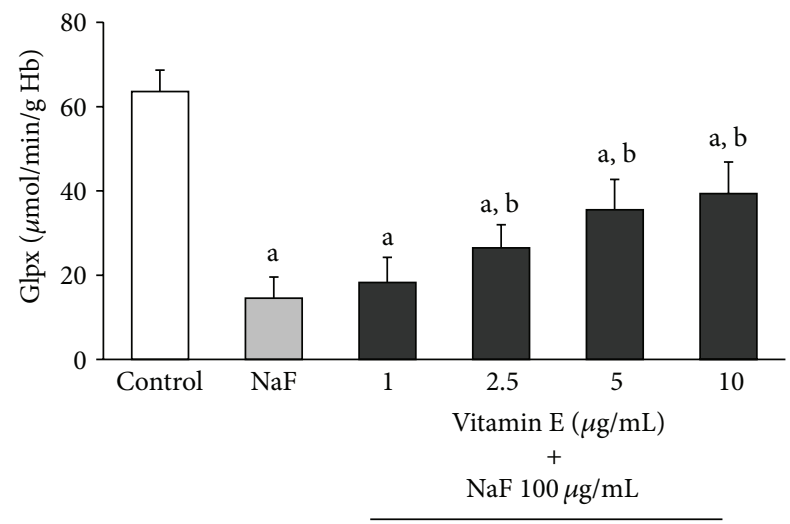

(b)

Figure 4: GlPx activity in erythrocytes incubated under the same conditions described in Figure 2. The results are expressed as the mean \pm standard deviation of five independent experiments, taking two samples per experiment and performing the determinations in triplicate. ${ }^{\mathrm{a}} P<0.05$ compared with the control group; ${ }^{\mathrm{b}} P<0.05$ compared with the group incubated with only $100 \mu \mathrm{g} / \mathrm{mL} \mathrm{NaF}$.

$7.5 \mu \mathrm{mol} / \mathrm{min} / \mathrm{g} \mathrm{Hg}(100 \mu \mathrm{g} / \mathrm{mL} \mathrm{NaF}+10 \mu \mathrm{g} / \mathrm{mL}$ Vit-E). This represents $61.94 \%$ of the activity of the control (Figure $4(\mathrm{~b})$ ).

\section{Discussion}

Fluoride is a very abundant ion in nature, where it only exists combined with other elements in fluoride compounds. The main source of fluoride for humans is the intake of water from underground aquifers contaminated with this element. The accumulation of fluoride in an organism causes fluorosis, which is manifested by damage in bone tissue as well as damage in several soft tissues and cell types such as muscle, liver, nervous system, and blood [1-3]. In areas with fluorosis, frequent hematologic alterations have been described. In vertebrates with fluorosis, hypochromic anemia, alterations in erythrocyte structure, and other hematologic alterations have been observed [3-9]. Moreover, in vitro experiments showed that alterations in metabolism as well as structural damage occur in erythrocytes exposed to fluoride compounds [10, 29].

Studies with experimental models in vivo and in vitro showed that in different tissues and cells, fluoride induces an excess of ROS production. Fluoride also decreases the biological activity of major antioxidant enzymes such as
SOD, CAT, and GIPx, which play an important role in ROS elimination $[11-15,30]$. However, although the mechanism by which fluoride causes these effects is not fully understood, it is thought that the generation of oxidative stress is an important part of the pathological damage mechanism induced by fluoride [11-14, 30]. Oxidative stress is an imbalance between ROS generation and the antioxidant systems. This imbalance results in damage to the major macromolecules of erythrocytes, membrane lipid peroxidation, and alterations in intermediate metabolism and hemoglobin properties $[8$, 9, 31-37]. In this study, we found that an in vitro increase in $\mathrm{NaF}$ concentration caused a corresponding increase in MDA concentration as well as decreases in the activities of SOD, CAT, and GIPx. Moreover, the presence of Vit-E in the culture media significantly inhibited the damage caused by NaF and was reflected in a decrease in MDA concentration (Figure 1) and a considerable increase in the activity of antioxidant enzymes (Figures 2 to 4 ).

Reports from in vitro and in vivo experiments, as well as data obtained from patients with fluorosis, indicate that $\mathrm{NaF}$ is an oxidative stress-causing agent. $\mathrm{NaF}$ increases ROS, which in turn increases MDA, as well as decreasing the activity of the major antioxidant enzymes such as SOD, CAT, and GIPx $[11-15,38]$.

The exact mechanism by which $\mathrm{NaF}$ produces these changes to the enzymatic systems associated with intermediate metabolism of the erythrocyte is not entirely known. However, it has been proposed that $\mathrm{NaF}$ causes these effects by interfering directly or indirectly with the main metabolic pathways of the cell. This results in an increase of ROS production and MDA concentration, caused by an alteration in the antioxidant enzymatic (e.g., SOD, CAT, and GIPx) and nonenzymatic (e.g., glutathione, urea, and Vit-E) defense systems $[1-3,11-15,38]$.

A probable direct mechanism by which $\mathrm{NaF}$ alters the activity of antioxidant enzymes is competitive substrate inhibition. This is due to the structural similarity between $\mathrm{NaF}$ and some of the known substrates for oxidoreductases and ion cotransporters present in cell membranes. Indirectly, another possible effect of $\mathrm{NaF}$ is inducing protein denaturation because of the effect of oxidative stress it causes in cells $[1-3,6,10-15,18,29,30,38]$.

Our results showed an increase in MDA concentration in the erythrocyte membrane accompanied by an alteration in the activity of antioxidant enzymes, which revealed the presence of oxidative stress in the erythrocyte caused by $\mathrm{NaF}[16-19,31,32]$. The observed damage in the erythrocyte membrane was partially prevented by the presence of Vit-E (a well-known antioxidant commonly used in in vitro and in vivo experiments), which can act as a "trap" (scavenger) for ROS, reducing the damage they cause [24, 35, 39, 40]. Vit-E concentrations of 5 and $10 \mu \mathrm{g} / \mathrm{mL}$ (reported as effective in decreasing ROS damage in vitro [24, 35, 39, 40]) were more effective in partially reducing the damage caused to the erythrocyte membranes by $\mathrm{NaF}$.

Furthermore, our results showed that $\mathrm{NaF}$ inhibited the activity of SOD, CAT, and GIPx in erythrocytes exposed to this toxic substance in a dose-dependent fashion. This indicates that the inhibition was more important as the 
amount of $\mathrm{NaF}$ added to the media increased, and at the same time, an increase in MDA concentration in the erythrocyte membrane was observed. Based on our findings, we hypothesize that one damage mechanism of $\mathrm{NaF}$ is the inhibition of antioxidant enzymes in the erythrocyte. This inhibition of antioxidant enzymes causes an excess of ROS, which damage the membrane of the erythrocyte, causing an increase in MDA concentration, in turn resulting in oxidative stress caused by this toxin. This oxidative stress is partially reversed by the presence of Vit-E.

The in vitro damage caused by $\mathrm{NaF}$ is partially reversed by vitamin E, which is a well-known natural antioxidant. Furthermore, there are reports of in vivo experiments where the pretreatment with vitamin $\mathrm{E}$ in combination with methionine and L-carnosine prior to the application of $\mathrm{NaF}$ resulted in significant reduction of the damage to various organs [41]. This points to the important role they can have as natural antioxidant compounds in preventing the toxic damage of $\mathrm{NaF}$. In this regard, in addition to vitamin E, other wellknown natural products (e.g., curcumin, N-acetylcysteine, and Ginkgo biloba), with antioxidant properties, have been used in in vivo and in vitro experiments to prevent or counteract the damage caused by free radicals generated by the intoxication with $\mathrm{NaF}$ and other toxic compounds that frequently contaminate the environment, mainly aquifers [41-45].

Our results show that the presence of Vit-E partially prevented the inhibition of the activity of antioxidant enzymes caused by NaF. We hypothesize that Vit-E may protect the erythrocyte membrane by "trapping" ROS that "attack" it. Nonetheless, the mechanism by which Vit-E prevents the inhibition of SOD, CAT, and GIPx antioxidant enzymes induced by $\mathrm{NaF}$ must be investigated in more detail. This could suggest how the damage this toxin causes in enzymatic systems and the cell in general can be avoided because the induction of oxidative stress in cells and hematopoietic tissues may be part of the physiopathological damage mechanism of this toxin.

\section{Conclusion}

In conclusion, the results observed in this study demonstrated that in human erythrocytes incubated in vitro in the presence of $\mathrm{NaF}$, there was an increase in MDA concentration in the membrane and significant deterioration in the activity of the antioxidant enzymes SOD, CAT, and GIPx. This deterioration caused by $\mathrm{NaF}$ was partially reverted by the presence of Vit-E, a well-known natural antioxidant.

\section{Conflict of Interests}

The authors declare that there is no conflict of interests.

\section{Acknowledgments}

This study was performed with the financial support of the "Programa de Investigación Científica y Tecnológica del ISSSTE" (Clave E015) from Instituto de Seguridad y Servicios
Sociales de los Trabajadores del Estado (ISSSTE), granted to Dr. José Gutiérrez-Salina, and partially supported by Grant from CONACyT (Fondo Sectorial en Salud; Salud 201201-181582) granted to Dr. Liliana García-Ortíz. The authors thank Mrs. Cinthia Santiago-Nicolas (Biomedical Research Division; CMN "20 de Noviembre," ISSSTE) for help with secretarial work.

\section{References}

[1] L. Li, "The biochemistry and physiology of metallic fluoride: action, mechanism, and implications," Critical Reviews in Oral Biology and Medicine, vol. 14, no. 2, pp. 100-114, 2003.

[2] R. G. Foulkes, “Thirty-five years of fluoride," Fluoride, vol. 35, no. 4, pp. 213-227, 2002.

[3] P. A. Monsour and B. J. Kruger, "Effect of fluoride on soft tissues in vertebrates," Fluoride, vol. 18, no. 1, pp. 53-61, 1985.

[4] Z. Guan, P. Yang, N. Yu, and Z. Zhuang, "An experimental study of blood biochemical diagnostic indices for chronic fluorosis," Fluoride, vol. 22, no. 3, pp. 112-118, 1989.

[5] F. Yur, F. Belge, N. Mert, and I. Yörük, "Changes in erythrocyte parameters of fluorotic sheep," Fluoride, vol. 36, no. 3, pp. 152156, 2003.

[6] D. Salara Kumari and P. Ramakrishna Rao, "Red cell membrane alterations in human chronic fluoride toxicity," Biochemistry International, vol. 23, no. 4, pp. 639-648, 1991.

[7] A. L. S. Seddek, A. Abdel-Hamid, T. A. Ibrahim, and M. A. El-Nasser, "Hematological and biochimical studies of fluoride poisoning in chicken a trial for treatment," Toxicology Letters, vol. 88, suppement 1, pp. 106-110, 1996.

[8] D. Saralakumari and P. R. Rao, "Red blood cell glucose metabolism in human chronic fluoride toxicity," Bulletin of Environmental Contamination and Toxicology, vol. 47, no. 6, pp. 834-839, 1991.

[9] M. Suska, R. Nowak, and B. Machalinski, "Serum fluoride and the content of adenine nucleotides and 2,3-bisphosphoglycerate in erythrocytes of rats exposed to sodium fluoride," Fluoride, vol. 36, no. 2, pp. 113-121, 2003.

[10] Ö. Korkmaz, "In vitro effects of sodium fluoride and sodium dichromate on dynamic properties of human erythrocyte membrane," Biophysical Chemistry, vol. 83, no. 2, pp. 111-120, 2000.

[11] D. Chlubek, "Fluoride and oxidative stress," Fluoride, vol. 36, no. 4, pp. 217-228, 2003.

[12] N. J. Chinoy, "Fluoride stress on antioxidant defence systems," Fluoride, vol. 36, no. 3, pp. 138-141, 2003.

[13] R. Rzeuski, D. Chlubek, and Z. Machoy, "Interactions between fluoride and biological free radical reactions," Fluoride, vol. 31, no. 1, pp. 43-45, 1998.

[14] D. Shanthakumari, S. Srinivasalu, and S. Subramanian, "Effect of fluoride intoxication on lipidperoxidation and antioxidant status in experimental rats," Toxicology, vol. 204, no. 2-3, pp. 219-228, 2004.

[15] O. Barbier, L. Arreola-Mendoza, and L. M. Del Razo, "Molecular mechanisms of fluoride toxicity," Chemico-Biological Interactions, vol. 188, no. 2, pp. 319-333, 2010.

[16] B. Halliwell and J. M. C. Gutteridge, "Oxygen free radicals and iron in relation to biology and medicine: some problems and concepts," Archives of Biochemistry and Biophysics, vol. 246, no. 2, pp. 501-514, 1986. 
[17] B. Halliwell, J. M. C. Gutteridge, and C. E. Cross, "Free radicals, antioxidants, and human disease: where are we now?" Journal of Laboratory and Clinical Medicine, vol. 119, no. 6, pp. 598-620, 1992.

[18] A. L. Tappel, "Lipid peroxidation damage to cell components," Federation Proceedings, vol. 32, no. 8, pp. 1870-1874, 1973.

[19] I. Dalle-Donne, R. Rossi, R. Colombo, D. Giustarini, and A. Milzani, "Biomarkers of oxidative damage in human disease," Clinical Chemistry, vol. 52, no. 4, pp. 601-623, 2006.

[20] J. Van Der Zee, J. Van Steveninck, J. F. Koster, and T. M. A. R. Dubbelman, "Inhibition of enzymes and oxidative damage of red blood cells induced by t-butylhydroperoxide-derived radicals," Biochimica et Biophysica Acta, vol. 980, no. 2, pp. 175180, 1989.

[21] J. T. Dodge, C. Mitchell, and D. J. Hanahan, "The preparation and chemical characteristics of hemoglobin-free ghosts of human erythrocytes," Archives of Biochemistry and Biophysics, vol. 100, no. 1, pp. 119-130, 1963.

[22] D. A. Ribeiro, C. Scolastici, M. E. A. Marques, and D. M. F. Salvadori, "Fluoride does not induce DNA breakage in Chinese hamster ovary cells in vitro," Brazilian Oral Research, vol. 18, no. 3, pp. 192-196, 2004.

[23] M. J. Aardema, D. P. Gibson, and R. A. LeBoeuf, "Sodium fluoride-induced chromosome aberrations in different stages of the cell cycle: a proposed mechanism," Mutation Research, vol. 223, no. 2, pp. 191-203, 1989.

[24] Z. Feng, Z. Liu, X. Li et al., " $\alpha$-Tocopherol is an effective Phase II enzyme inducer: protective effects on acrolein-induced oxidative stress and mitochondrial dysfunction in human retinal pigment epithelial cells," Journal of Nutritional Biochemistry, vol. 21, no. 12, pp. 1222-1231, 2010.

[25] O. H. Lowry, N. J. Rosebrough, A. L. Farr, and R. J. Randal, "Protein measurement with the Folin phenol reagent," The Journal of Biological Chemistry, vol. 193, no. 1, pp. 265-275, 1951.

[26] K. Yagi, "Simple assay for the level of total lipid peroxides in serum or plasma," Methods in Molecular Biology, vol. 108, pp. 101-106, 1998.

[27] J. V. Bannister and W. H. Bannister, "Isolation and characterization of superoxide dismutase," Methods in Enzymology, vol. 105, pp. 88-93, 1984.

[28] E. J. V. Kampen and W. G. Zijlstra, "Determination of hemoglobin and its derivatives," Advances in Clinical Chemistry, vol. 8, no. C, pp. 141-187, 1966.

[29] N. I. Agalakova and G. P. Gusev, "Fluoride-induced death of rat erythrocytes in vitro," Toxicology in Vitro, vol. 25, no. 8, pp. 1609-1618, 2011.

[30] P. Y. Mochidome, A. Simões, E. Ganzerla, D. N. Souza, F. N. Nogueira, and J. Nicolau, "Effects of single exposure of sodium fluoride on lipid peroxidation and antioxidant enzymes in salivary gland of rats," Oxidative Medicine and Cellular Longevity, vol. 2013, Article ID 674593, 7 pages, 2013.

[31] J. Van Der Zee, T. M. A. R. Dubbelman, and J. Van Steveninck, "Peroxide-induced membrane damage in human erythrocytes," Biochimica et Biophysica Acta, vol. 818, no. 1, pp. 38-44, 1985.

[32] F. Nielsen, B. B. Mikkelsen, J. B. Nielsen, H. R. Andersen, and P. Grandjean, "Plasma malondialdehyde as biomarker for oxidative stress: reference interval and effects of life-style factors," Clinical Chemistry, vol. 43, no. 7, pp. 1209-1214, 1997.

[33] J. F. S. J. Dwight and B. M. Hendry, "The effects of tert-butyl hydroperoxide on human erythrocyte membrane ion transport and the protective actions of antioxidants," Clinica Chimica Acta, vol. 249, no. 1-2, pp. 167-181, 1996.
[34] C.-K. Lii and C.-N. Hung, "Protein thiol modifications of human red blood cells treated with t-butyl hydroperoxide," Biochimica et Biophysica Acta, vol. 1336, no. 2, pp. 147-156, 1997.

[35] N. R. Brownlee, J. J. Huttner, R. V. Panganamala, and D. G. Cornwell, "Role of vitamin $\mathrm{E}$ in glutathione-induced oxidant stress: methemoglobin, lipid peroxidation, and hemolysis," Journal of Lipid Research, vol. 18, no. 5, pp. 635-644, 1977.

[36] H. R. Andersen, J. B. Nielsen, F. Nielsen, and P. Grandjean, "Antioxidative enzyme activities in human erythrocytes," Clinical Chemistry, vol. 43, no. 4, pp. 562-568, 1997.

[37] B. Tavazzi, D. Di Pierro, A. M. Amorini et al., "Energy metabolism and lipid peroxidation of human erythrocytes as a function of increased oxidative stress," European Journal of Biochemistry, vol. 267, no. 3, pp. 684-689, 2000.

[38] N. I. Agalakova and G. P. Gusev, "Molecular mechanism of cytotoxicity and apoptosis induced by inorganic fluoride," International Scholarly Research Network, Cell Biology, vol. 2012, Article ID 403835, 16 pages, 2012.

[39] B. A. Wagner, G. R. Buettner, and C. P. Burns, "Vitamin E slows the rate of free radical-mediated lipid peroxidation in cells," Archives of Biochemistry and Biophysics, vol. 334, no. 2, pp. 261267, 1996.

[40] R. Ricciarelli, J.-M. Zingg, and A. Azzi, "Vitamin E: protective role of a Janus molecule," FASEB Journal, vol. 15, no. 13, pp. 23142325, 2001.

[41] F. E. Agha, M. O. El-Badry, D. A. A. Hassan, and A. A. Elraouf, "Role of vitamin $\mathrm{E}$ in combination with methionine and Lcarnosine against sodium fluoride-induced hematological, biochemical, DNA damage, histilogical and immunohistochemical changes in pancreas of albino rats," Life Science Journal, vol. 9, no. 2, pp. 1260-1275, 2012.

[42] C. Zhang, C. Ren, H. Chen et al., "The analog of Ginkgo biloba extract 761 is a protective factor of congnitive impairment induced by chronic fluorosis," Biological Trace Element Research, vol. 153, no. 1-3, pp. 229-236, 2013.

[43] H. Tiwari and M. V. Rao, "Curcumin supplementation protects from genotoxic effects of arsenic and fluoride," Food and Chemical Toxicology, vol. 48, no. 5, pp. 1234-1238, 2010.

[44] S. F. Nabavi, S. M. Nabavi, M. A. Ebrahimzadeh, S. Eslami, N. Jafari, and A. Hajizadeh Moghaddam, "The protective effect of curcumin against sodium fluoride-induced oxidative stress in rat heart," Archives of Biological Sciences, vol. 63, no. 3, pp. 563569, 2011.

[45] C. D. Anuradha, S. Kanno, and S. Hirano, "Oxidative damage to mitochondria is a preliminary step to caspase- 3 activation in fluoride-induced apoptosis in HL-60 cells," Free Radical Biology and Medicine, vol. 31, no. 3, pp. 367-373, 2001. 

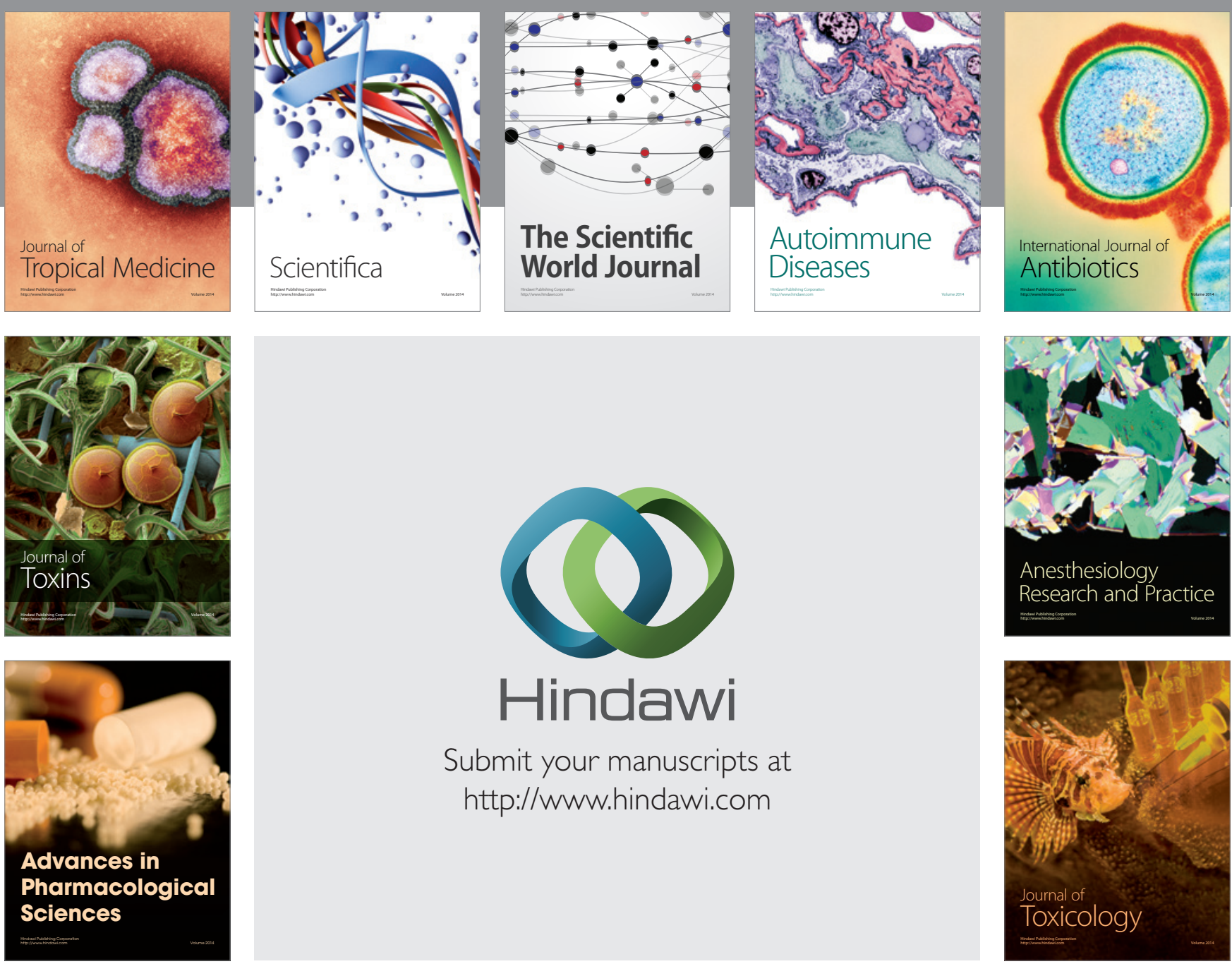

\section{Hindawi}

Submit your manuscripts at

http://www.hindawi.com
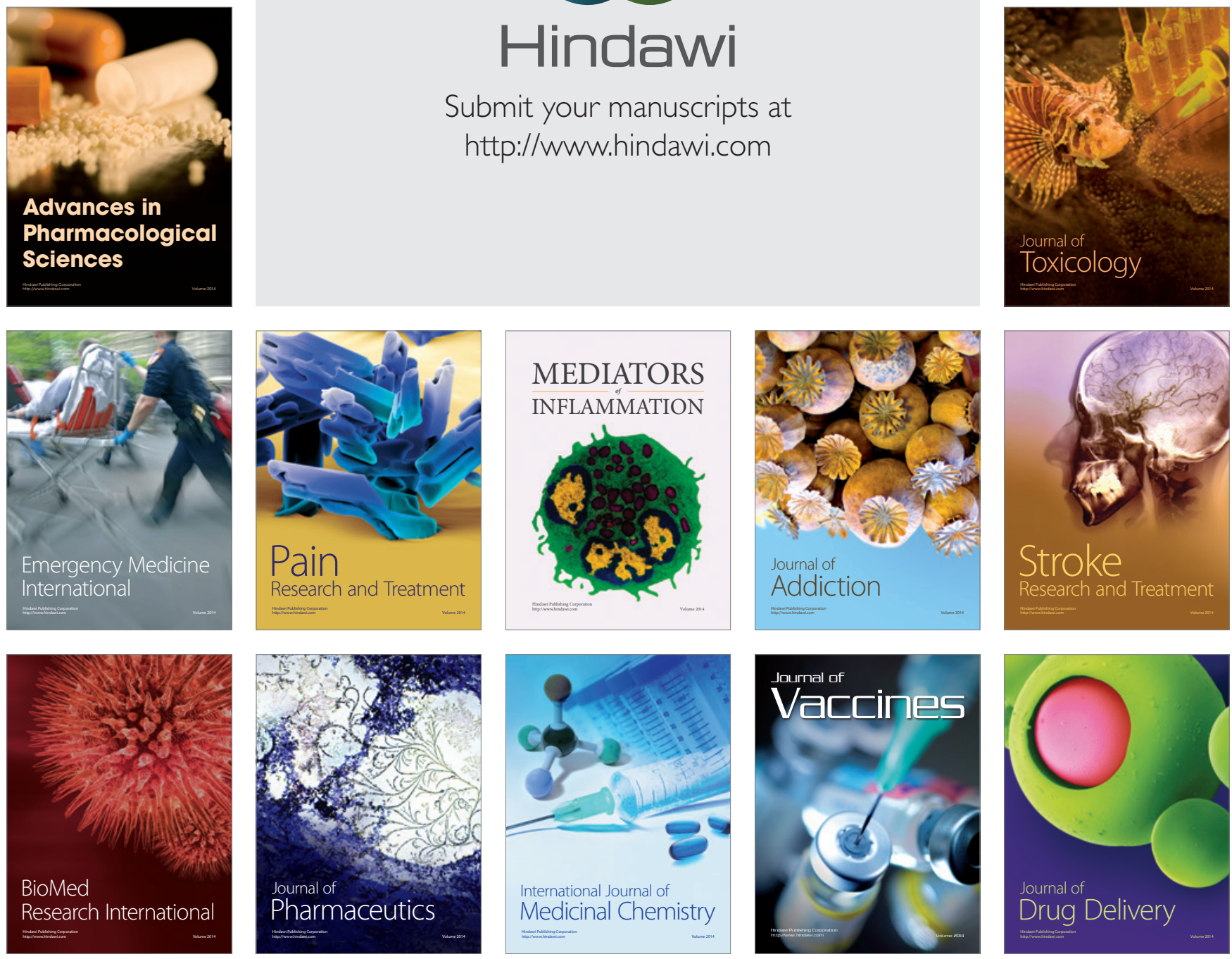